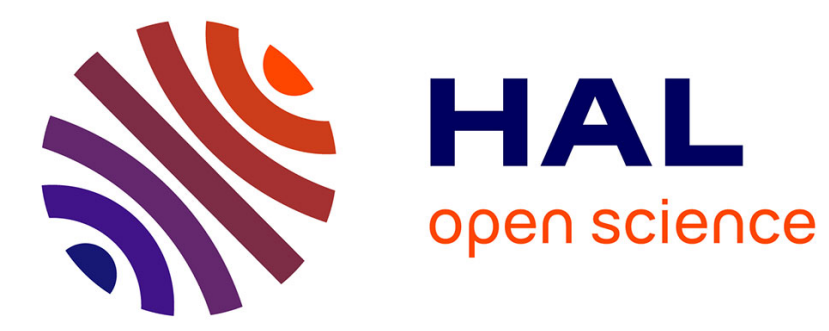

\title{
Extension of SuperDARN at Dome C.
}

\author{
J.-P. Villain, E. Amata, Jean-Claude Cerisier
}

\section{To cite this version:}

J.-P. Villain, E. Amata, Jean-Claude Cerisier. Extension of SuperDARN at Dome C.. EAS Publications Series, 2005, 14, pp.107-112. hal-00156202

\section{HAL Id: hal-00156202 \\ https://hal.science/hal-00156202}

Submitted on 2 Apr 2021

HAL is a multi-disciplinary open access archive for the deposit and dissemination of scientific research documents, whether they are published or not. The documents may come from teaching and research institutions in France or abroad, or from public or private research centers.
L'archive ouverte pluridisciplinaire HAL, est destinée au dépôt et à la diffusion de documents scientifiques de niveau recherche, publiés ou non, émanant des établissements d'enseignement et de recherche français ou étrangers, des laboratoires publics ou privés. 


\title{
EXTENSION OF SUPERDARN AT DOME C
}

\author{
J.-P. Villain ${ }^{1}$, E. Amata ${ }^{2}$ and J.-C. Cerisier ${ }^{3}$
}

\begin{abstract}
The SuperDARN (Super Dual Auroral Radar Network) experiment is a multi-national effort to develop chains of coherent HF radars world wide in order to obtain instantaneous large scale coverage of the magnetospheric plasma convection at high spatial and temporal resolution. We will review the scientific context of the experiment. The role of SuperDARN in our understanding of Sun-Earth relations will be emphasized through its numerous scientific objectives. The principle of the experiment will be described and specific capabilities and achievements presented, as well as its implication in the Space Weather program. Finally, the implementation of SuperDARN radars at Dome $\mathrm{C}$ is presented together with the prospective global extension of the network in both hemispheres.
\end{abstract}

\section{Geophysical Context}

The Sun activity is the primary source of numerous processes influencing the Earth environment. The solar wind, permanent flow of electrically charged particles streaming out of the Sun corona, tends to confine the Earth and its magnetic field in a comet shapes cavity called the magnetosphere. At the Earth orbit, the velocity of the solar wind varies between 300 and $800 \mathrm{~km} \mathrm{~s}^{-1}$ and the density of particles is between 1 and part $/ \mathrm{cm}^{3}$.

Inside the magnetosphere, the electrodynamics or motion of the ionized gas depends strongly on the external conditions imposed by the solar wind and the interplanetary magnetic field at the limits of the magnetosphere. These interactions taking place at the magnetospheric boundaries are mapped to lower altitudes into the ionosphere (ionized part of the upper atmosphere), between 100 and $300 \mathrm{~km}$ altitude, mostly in the high-latitude regions where the magnetic field lines from the outer part of the magnetosphere are converging.

\footnotetext{
${ }^{1}$ LPCE/CNRS, Orléans, France

2 IFSI, Roma, Italy

${ }^{3}$ CETP/CNRS, Saint-Maur, France
} 
These regions are known as the auroral zones, looking like crowns around the north and south magnetic poles, where auroras are observed. Figure 1 presents a schematic diagram of the magnetosphere, with all the different regions that have been identified. These regions are classified through their population of particles (density, energy, etc.), the currents circulating and the physical processes taking place.

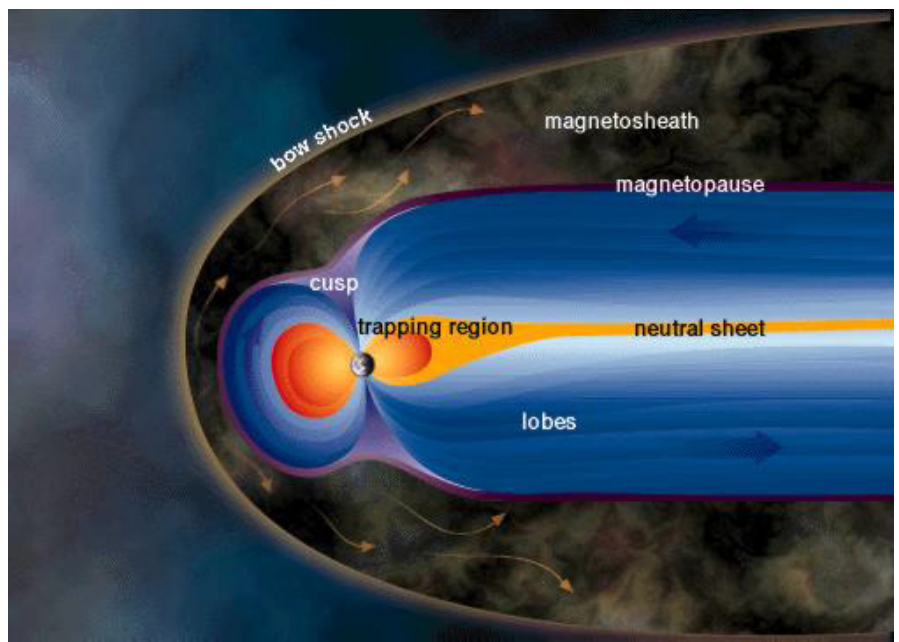

Fig. 1. Schematic view of the magnetosphere and its coupling with the ionosphere.

\section{The Magnetospheric Plasma Convection}

The solar wind-magnetosphere-ionosphere system works as a gigantic dynamo. The solar wind flowing through the Earth's magnetic field $\boldsymbol{B}$ lines generate an electric field $\boldsymbol{E}$. This $\boldsymbol{E}$ field is mapped along the highly conducting Earth's magnetic field lines into the ionosphere at an altitude of approximately $110 \mathrm{~km}$ where horizontal currents can flow to cross the electrical circuit. This $\boldsymbol{E}$ field produces then a motion of the ionospheric plasma perpendicularly to the Earth's magnetic field through the basic magneto-hydrodynamic law $\boldsymbol{V}=(\boldsymbol{E} \times \boldsymbol{B}) / \boldsymbol{B}^{\mathbf{2}}$. There is an anti-sunward motion on the open field lines (Earth's magnetic field lines reconnected directly with the Interplanetary Magnetic Field - IMF), with a return flow on the closed field lines inside the magnetosphere. At equilibrium, when mapped to the ionosphere, this create convection cells whose number, size, orientation and Dynamics are directly linked to the IMF.

The primary goal of the SuperDARN project is to give instantaneous pictures of the whole plasma convection in both hemispheres in order to follow its evolution as a function of the solar wind parameters. 
The main research topics can be summarized as follows:

Global scale magnetospheric convection:

- Topology of convection cells as a function of IMF.

- Dynamics of restructuration.

Intermediate scale structures:

- Day side: FTE (Flux Transfert Events), Pressure pulses.

- Night time: Magnetic substorms.

North-South conjugacy:

- Opposite effects of the By component of IMF.

- Seasonal effects: Conductivity difference between hemispheres, closing of magnetospheric currents.

Ionosphere-Magnetosphere Coupling:

- Field aligned currents.

- Alfven waves.

Ionosphere-Thermosphere Coupling: Gravity waves.

Plasma Turbulence:

- Plasma Instability Mecanisms.

- Turbulence characteristics: Diffusion Coefficient, etc.

Other programmes support:

- SuperDARN is integrated to all space missions for magnetospheric studie.

- Incoherent scatter radars.

\section{The Instrument: HF Coherent Radar}

H.F. radars are able to detect the motion of the plasma in the ionosphere at very large distances. They transmit radio waves at any frequency between 8 and $20 \mathrm{MHz}$, which are then refracted into the ionosphere to, reach perpendicularity to the Earth magnetic field in the auroral zone and the polar cap, near $300 \mathrm{~km}$ altitude. A very small part of the energy is backscattered by irregularities present in the plasma and comes back toward the radar where it is detected and analyzed. The backscattered part of the wave suffers a change inn frequency proportional to the radial component of the plasma velocity (Doppler effect).

\section{The Network Concept}

The aim of SuperDARN (Greenwald et al. 1995) is to produce instantaneous global maps of magnetospheric plasma convection with a high spatial and temporal resolution in both hemispheres.

This is obtained through a network of coordinated OTH (Over The Horizon) HF radars regularly distributed in longitude around the auroral zones in both hemispheres.

Each sector of longitude is covered by two radars located at distant locations to obtain vectorial information. Figure 2 presents the fields of view of the existing radars. Sixteen radars are operational. 
At the moment ten countries are involved in the SuperDARN project (in alphabetical order): - Australia - Canada - France - Finland - Italy - Japan South Africa - Sweden - UK - USA and China is a potential partner through plans at the Antarctic base of Zhongshan.

The technical characteristics are the following:

Paired Radars: Measurement of 2 radial components of velocity vectors perpendicular to $\mathrm{B}$.

- Distance coverage: 75 range gates of $45 \mathrm{~km}$ (180-3550 km from radar).

- Azimuthal coverage: $52^{\circ}$ - 16 directions by 3.3 steps.

- Integration time: 3 or $7 \mathrm{~s}$ (complete scan in 1 or $2 \mathrm{~min}$ ).

- Fully unmanned experiment with remote control.

The radars are operated through an international agreement with the following rules:

- Identical Radars.

- Each radar under the responsibility of one or more groups.

- Same software control.

- Coordinated Observations (schedule defined 2 months in advance).

- Same data format.

- Merge data.
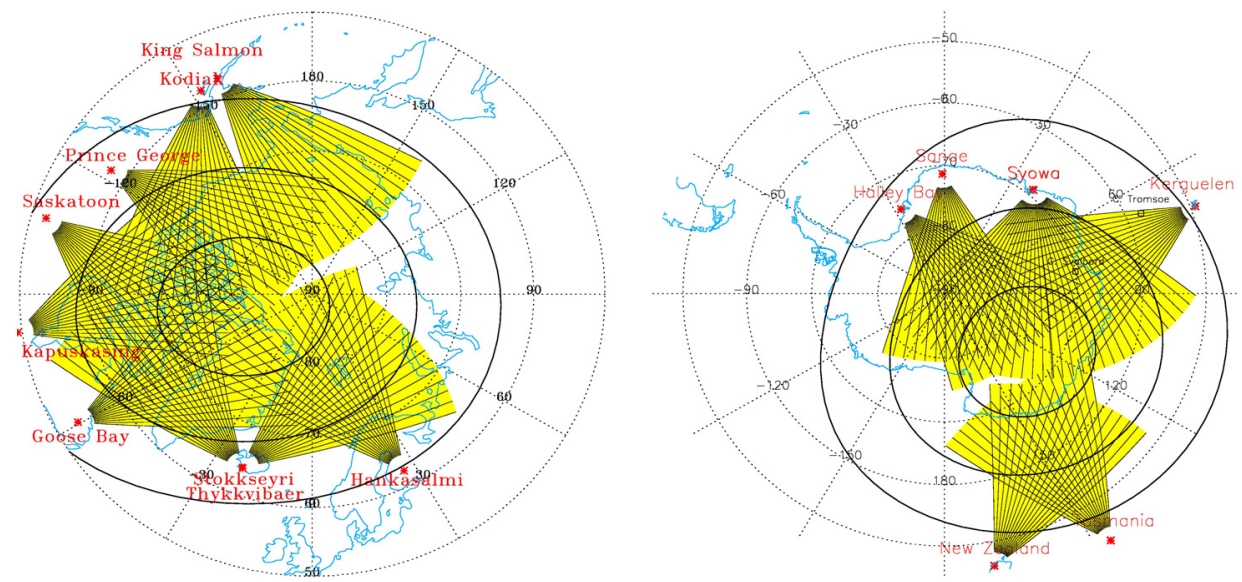

Fig. 2. Fields of view of the existing SuperDARN radars for the Northern and southern hemispheres.

\section{Dome C Radars}

Why Dome C? It is the only location in the southern hemisphere to locate radars to fill the gaps in the Indian and Pacific oceans. Figure 3 presents the southern hemisphere fields of view with Dome $\mathrm{C}$ radars superimposed in orange. 
The Dome C features can be summarized as follow:

- The only location for a global coverage in the southern hemisphere.

- Paired with a US radar at South Pole and a Chinese radar at Zhongshan (see Fig. 4).

- French-Italian project with equal sharing of cost and responsibilities.

- Continuation of the existing collaboration for the Kerguelen radar.

- Part of an international effort for a better understanding of Sun-Earth relations.

- Support of Space Weather programme and all magnetospheric space missions.

- SuperDARN is the only adequate experiment for studying magnetic conjugacy.

Two building options have been defined:

- Option 1: two antenna fields + one set of electronics commutated between the antenna fields (lower temporal resolution).

- Option 2: two full radars operated independently.

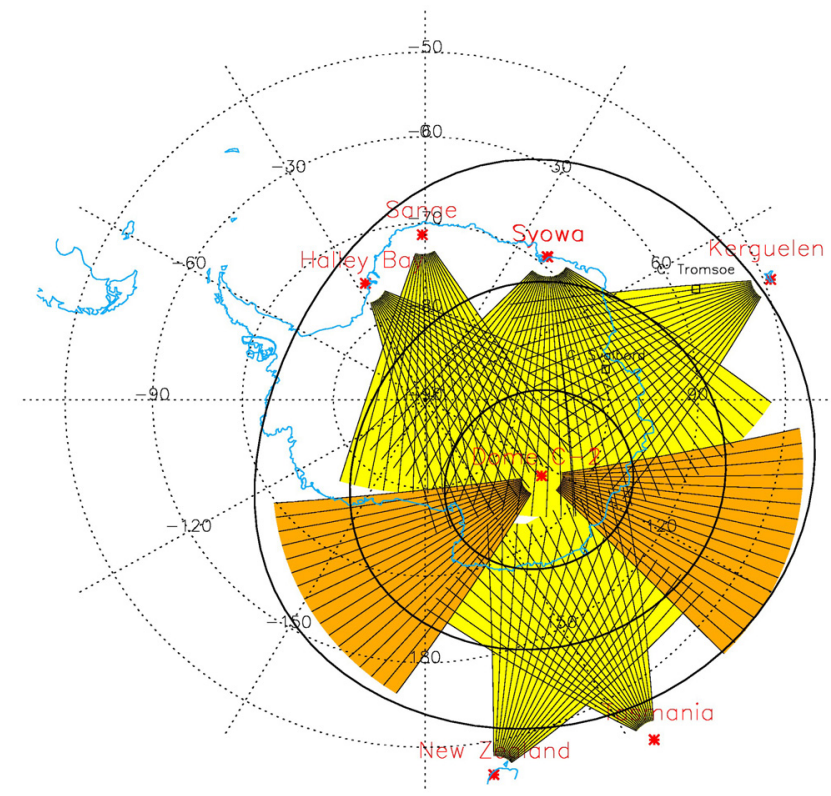

Fig. 3. Fields of view of the proposed Dome C SuperDARN radars in orange Super posed on the existing radars in yellow.

Dome C Technical points:

- Need of full reflection in ionosphere to achieve perpendicularity to Earth magnetic field, more difficult to achieve.

- Advantage: the Dome C radars should not suffer loss of signal for higher magnetic activity. 


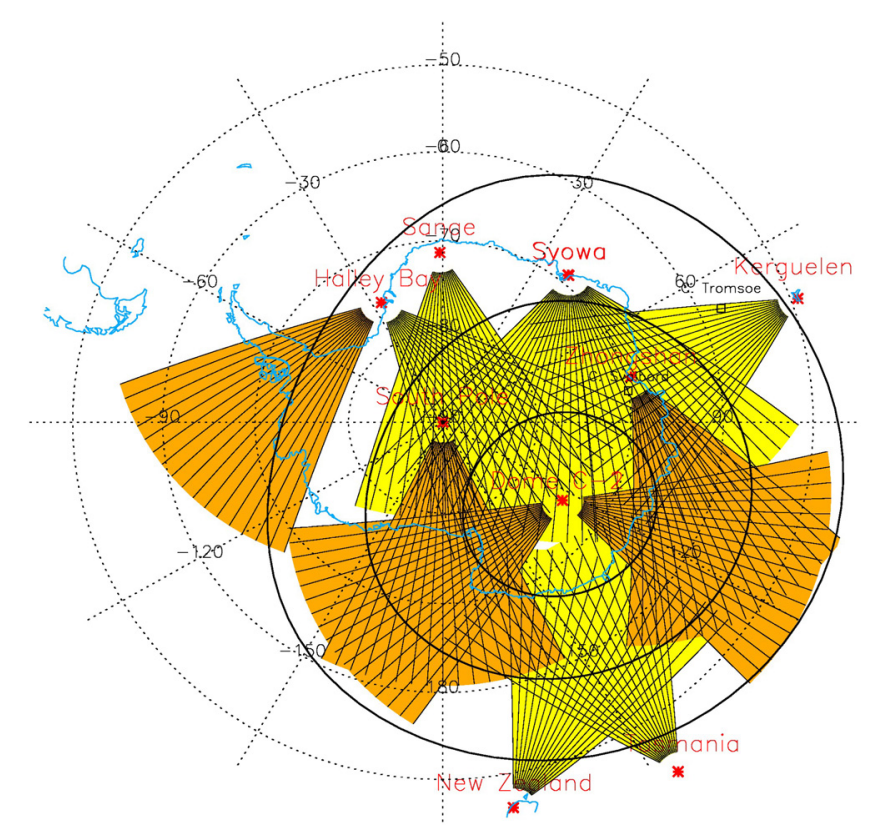

Fig. 4. Fields of view of SuperDARN radars in the southern hemisphere including existing radars in yellow, the Dome $\mathrm{C}$ radars, the South Pole and Zhongshan radars paired with thee Dome $\mathrm{C}$ radars, as well as a project of the British Antarctic survey to implement a second radar at Halley Bay.

Logistic and infrastructure:

- Technical meeting at IPEV last October.

- No hard point foreseen.

- Many other SD radars run in similar environments $\left(T<-40^{\circ} \mathrm{C}\right)$.

- Electric power requirement at max $1.5 \mathrm{KW}$ continuous

Manpower:

- Preparation of site: TBD by IPEV and PNRA.

- Construction of antennas and implementation of container: $-6 \mathrm{man} / \mathrm{month}$.

- Operation of radar: $10 \%$ of permanent wintering person.

Maintenance visit: every 3 years (as in Kerguelen).

\section{References}

Greenwald, R.A., Baker, K.B., Dudeney, J.R., et al. 1995, DARN/SuperDARN: A global view of the dynamics of high-latitude convection, Space Sci. Rev., 71, 761 